\title{
The Impact of the Fourth Industrial Revolution on Student Mobility from the Perspective of Education Economics
}

Takashi Sekiyama

GSAIS, Kyoto University, Kyoto, Japan

\section{ABSTRACT}

This paper is to explore the challenges the student mobility will face under the fourth industrial revolution from the perspective of education economics. The Fourth Industrial Revolution affects not only economic activities such as production, sales, and consumption, but it also has an impact on education. Few previous studies, however, have explored the influence on international student mobility in the higher education sector. How does the Fourth Industrial Revolution change the cost-utility structure of studying abroad? What challenges do higher education institutions face? This paper analyzes the impact of the Fourth Industrial Revolution by employing an economic theoretic model. Some of the socio-economic changes caused by the Fourth Industrial Revolution, such as an increased global knowledge stock, increase demand for study abroad, while others including knowledge that rapidly becomes obsolete and the relatively high costs of studying abroad, reduce it. Higher education institutions not only face risks but also have opportunities in the era of the Fourth Industrial Revolution. The key to their success is in providing more opportunities to develop the non-cognitive skills necessary for jobs that machines cannot do.

Keywords:

Fourth Industrial Revolution, Higher Education, Education Economics, Student Mobility

\section{Introduction}

As the Fourth Industrial Revolution progresses, it affects not only economic activities such as production, sales and consumption, but also a wide range of fields such as health, medical care and public services, not to mention its impact on the way people work and their lifestyles. With the development of information and communication technology (ICT), new economic value is created by converting consumers' economic activity into big data. Big data combined with artificial intelligence (AI) enables not only information analysis but also the provision of labor and services that involve complex judgments by machines, and this is expected to contribute to the resolution of various social problems.

Researchers have also been examining the impact of the Fourth Industrial Revolution on higher education. Higher Education in the Era of the Fourth Industrial Revolution (Gleason, 2018), for example, examines how higher education responds to the demands of the automation economy. Quacquarelli Symonds (QS), a leading global higher education company, held an international conference titled "Industrial Revolution 4.0 and Aging Societies: The Changing Roles of Universities in the AsiaPacific" in Japan in 2019 to address both the challenges and opportunities of the Fourth Industrial Revolution (Linney, 2019). The World Economic Forum, a primary advocate for the Fourth Industrial Revolution, also states that education models 
need to reflect the demand for lifelong learning in order to cope with the technological and social changes that it brings (World Economic Forum, 2019).

Few previous studies, however, have explored the influence of the Fourth Industrial Revolution on student mobility in the higher education sector. The dynamics of international student mobility are influenced by educational, political, social, cultural and economic factors. In this regard, educational economics is a useful way to analyze the microstructure that influences individual decisions made by students and governments.

This paper explores the challenges of international student mobility in the higher education sector under the Fourth Industrial Revolution from the perspective of educational economics. How does the Fourth Industrial Revolution change the costutility structure of study abroad? What challenges do higher education institutions face? This paper analyzes the impact of the Fourth Industrial Revolution by employing theoretical modeling. It also discusses the implications obtained from the theoretical model and the possible impacts of the Fourth Industrial Revolution on international students' desire and ability to study abroad.

\section{Methods and Results}

The education economy argues that studying abroad can be seen as "consumption" of individual intellectual desires and "investment" in human capital. The question is whether study abroad can pay off even in the era of the Fourth Industrial Revolution. No matter if the motivation is "consumption" or "investment", as long as the utility associated with study abroad exceeds the costs, study abroad has worth for the student. The Fourth Industrial Revolution, however, is likely to have significant impacts on the cost-utility structure of study abroad. This section first explores such socio-economic impacts brought about by the Fourth Industrial Revolution through literature review. A mathematical economic model of study abroad is then developed by taking the literature review into account.

\subsection{Literature Review: Impacts Brought about by the Fourth Industrial Revolution}

\subsubsection{The Increase of Global Knowledge Stock and Its Obsolescence}

The Fourth Industrial Revolution significantly enhances the global capacity for creation of knowledge and the speed at which it is produced. This increases the volume of global knowledge stock. On the other hand, a rapid increase in knowledge also means that obsolescence accelerates.

The knowledge society is emerging from the simultaneous growth of the internet, mobile telephony, and digital technologies which have revolutionized the role of knowledge in our societies (Bindé et al., 2005). The capacity to gather and analyze information has existed throughout human history. The concept of the present-day knowledge society, however, is based on the vast increases in data creation and information dissemination that result from innovation in information technologies. What makes the knowledge society exceptional are the quantities of knowledge and information produced daily and the use of ICT in data-intensive processes (Vallima \& Hoffman, 2008).

Artificial intelligence and machine learning in the Fourth Industrial Revolution move both information and knowledge creation forward in their capacities to use intelligence to digitally create meaning independent of user-driven ICT, making a knowledge society different to an information society. The former serves to transform information into resources that allow society to take effective actions for 
the improvement of human circumstances, but the latter only creates and disseminates raw data. Information alone does not create knowledge. During the Third Industrial Revolution, the evolution of the internet enabled individuals to connect anywhere and anytime wherever digital technologies were accessible. The capacity for individuals to produce and use data on a global scale, however, does not always result in knowledge creation. For knowledge creation to take place, there are requirements to create awareness, meaning and understanding (Castelfranchi, 2007). The anticipated new technologies in the Fourth Industrial Revolution make it possible for machines to learn from experience, perform human-like tasks, and help convert information into knowledge.

Universities must equip graduates with "cross-skills" which are non-cognitive skills in communication, translation between technology and practice, empathy, and critical thinking. Most university curriculums are designed around consumption of knowledge. However, in a time when computers can extract information from thousands of textbooks in a second, humans consuming the content of tens of textbooks is relatively insignificant. Similarly, in an age where intelligent machines can perform countless tasks in a moment, it is not necessary for many people to become proficient in similar tasks. Rather, the challenges of the Fourth Industrial Revolution require cross-skills. Future leaders must be able to imagine a new society and address its challenges.

\subsubsection{Enhancing Global Connectivity without Physical Movement}

In the Fourth Industrial Revolution society, people can be globally connected without having to physically travel. The biggest impacts of the Third Industrial Revolution were computerization and web-based interconnectivity developed in the 1980s and 1990s. As information technology further develops in the Fourth Industrial Revolution, online communication could displace traditional in-person communication. This may greatly influence both learning methods and working styles for the next generation.

Future students will learn in different ways than they have in the past, and developments in information technology could influence students' mobility and desire to study abroad. The development of information technology such as massive online open courses (MOOCs) could expand access to university education for millions of previously underserved students around the world (Asmaa, 2016). Even if this does not turn out to be the case, the necessity for study abroad may decrease significantly due to the spread of online courses.

On the other hand, online and tech-enhanced teaching within universities may enable universities to teach students with diverse backgrounds more efficiently, and to open up their campuses to a more global community of both faculty and students. One example of an initiative of this sort is EdX. EdX was originally founded by MIT and Harvard University to offer MOOCs. Now, a growing number of elite universities are offering online graduate and certificate programs. More than a few Asian-Pacific universities can be found in the list of its charter members, including Australia National University, Kyoto University in Japan, Peking University in China, Seoul National University in South Korea, and The National University of Singapore (EdX, 2019). Likewise, online courses can expand access to higher education and help students and workers all over the world to update the necessary skills in a fastchanging Fourth Industrial Revolution society.

In addition to the development of information technology, another factor influencing study abroad is the creation of entirely new institutions with more global and interdisciplinary curriculums and a greater emphasis on strong collaborations between students within a residential community (Penprase, 2018). One example is the Yale-NUS College in Singapore, instituted by Yale University and the National 
University of Singapore to provide a residential liberal arts college within Asia. YaleNUS College offers a range of interdisciplinary science courses and quantitative reasoning, literature and philosophy from both Eastern and Western cultures. At this college local students are able to develop skills necessary in the era of the Fourth Industrial Revolution without leaving their home city.

\subsubsection{Increasing Inequality}

One of the biggest social impacts brought about by the Fourth Industrial Revolution is the increase in the income gap between rich and poor that the Third Industrial Revolution helped to create. For example, Oxfam estimated in 2017 that just eight men had the same wealth as the poorest half of the world (Hardoon, 2017). Another report stated that the bottom half of wealth holders collectively accounted for less than $1 \%$ of total global wealth in 2019 , while the richest $10 \%$ had $82 \%$ of global wealth and the top $1 \%$ alone had $45 \%$ (Shorrocks, Davies, \& Lluberas, 2019). As technology growth benefits the richest, the rest of society, especially the poorest, suffers. The very design of our economies and our economic principles have taken us to this extremely unsustainable and unjust point.

As a result of increased automation and mechanization as part of the Fourth Industrial Revolution, business owners, capitalists, and highly skilled workers are expected to experience significant economic benefits. In an economy where machines and computers create greater value, capitalists who invest in them benefit. Employers and business owners also benefit from better mechanization, as labor costs can be reduced. It is also anticipated that many new jobs will be created for highly skilled workers in fields such as IT, mathematics, architecture, and engineering. Automation, on the other hand, can drive low and medium-skilled people into unemployment or lower salaried jobs.

According to a report from the financial institution UBS, the Fourth Industrial Revolution will lead to a polarization of the labor market and widening income inequality. This is because those with income, skills, and assets will experience greater benefits. The report also forecasts that industries such as manufacturing will return to developed countries as technologies such as robotics, automation, and 3D printing become more widespread. These technologies can provide products and services more cheaply than offshore low-wage workers. As a result, the Fourth Industrial Revolution will be relatively advantageous for developed countries. On the other hand, developing countries will lose the comparative advantage of their abundant low-skilled workforces. Developing countries are likely to face even greater difficulties during the Fourth Industrial Revolution (Baweja et al., 2016).

Given that poor families cannot afford to give their children higher education, the inequality brought about by the Fourth Industrial Revolution reproduces the disparity between rich and poor that is seen in educational inequality. The human capital theory argues that those who have acquired higher skills through education are more likely to earn higher incomes. In the Fourth Industrial Revolution system, highly educated people will have the advantage. However, higher education is a costly investment, and the ability to make that investment depends largely on the financial situation of the student and their family.

\subsection{Economic Model of Study Abroad}

This section develops a mathematical economic model of study abroad by taking into account the review in the previous section.

\subsubsection{Costs and Utilities}


The cost of studying abroad includes tuition and living expenses, as well as the income the student would have received by working at home. An individual chooses to study abroad when the benefits gained by studying abroad exceed these costs.

On the other hand, studying abroad offers additional benefits. One is an increase in lifetime income. Human capital theory states that a major component of education economics is the knowledge and skills acquired through education as capital generates private and public benefits in the future. Undertaking higher education is an important method of accumulating human capital. In particular, studying abroad may allow students to accumulate human capital in ways not possible in their home countries and may enable them to earn higher incomes in the future. From this reasoning, Gerhard and Hans (2013) regard studying abroad as "transnational human capital", while Murphy-Lejeune (2002) conceptualize it as "mobility capital".

The benefits of studying abroad are not limited to increased lifetime income. On the consumption side, the joy of living abroad and experiencing different cultures is also an important benefit. In other words, the individual may choose to study abroad when the utility, including not only the expected increase in lifetime income but also the consumption aspect, exceeds the costs.

\subsubsection{Model}

Such individual motivation to study abroad can be expressed by a mathematical economic model. Since individuals form human capital by receiving education, the function of human capital accumulation can be assumed as follows:

$$
\mathrm{h}=\mathrm{kHh}=\mathrm{kH} \text { [function of human capital development](1) }
$$

Here, $\mathrm{h}$ is the amount of human capital of an individual, $\mathrm{k}$ is the knowledge acquisition rate, and $\mathrm{H}$ is the knowledge stock that exists worldwide. In other words, the function (1) indicates that an individual's human capital is determined by how much knowledge that exists in society can be acquired. Here, the following function (2) is obtained assuming that the knowledge acquisition rate $\mathrm{k}$ depends on the education level e that the individual receives. Note that $\mathrm{k}(0)=0, \mathrm{k}^{\prime}>0$, and $\mathrm{k}^{\prime \prime}<0$.

$$
\mathrm{k}=\mathrm{k}(\mathrm{e}) \mathrm{k}=\mathrm{k}(\mathrm{e})(2)
$$

It is assumed that the global knowledge stock changes with the power of the representative individual's human capital level h. The change in the amount of global knowledge stock is represented by $\mathrm{H}^{\circ} \mathrm{H}^{\circ}$. It is important to note, however, that knowledge becomes obsolete over time. Particularly in the era of the Fourth Industrial Revolution, the speed of knowledge obsolescence is expected to accelerate faster than ever before. It cannot be ignored. Therefore, the global knowledge stock is discounted at a constant rate $\delta(0<\delta<1) \delta(0<\delta<1)$.

$\mathrm{H}^{\cdot}=\varepsilon \mathrm{h}^{-} \beta-\delta \mathrm{HH}^{*}=\varepsilon \mathrm{h}^{-} \beta-\delta \mathrm{H}$ [function of global knowledge stock accumulation](3) Suppose an individual has a utility function (4) consisting of a preference e for studying abroad and a preference $c$ for any other consumption. It is assumed here that study abroad preferences change according to the global knowledge stock. A large global knowledge stock means that there is a lot of knowledge for individuals to acquire. In that case, individuals will be able to expect more lifetime income through acquiring knowledge than those who do not study abroad. Also, the desire to learn and intellectual curiosity stimulates individuals and increases their preference for studying abroad.

$$
\mathrm{U}=\mathrm{c}+\alpha(\mathrm{H}) \mathrm{v}(\mathrm{e}) \mathrm{U}=\mathrm{c}+\mathrm{a}(\mathrm{H}) \mathrm{v}(\mathrm{e}) \text { [utility function](4) }
$$

Human capital theory considers that the amount an individual produces through labor is proportional to their human capital. The budget constraint equation of the individual is expressed as the following function (5). Here, $w$ is the wage rate, $T$ is the tax, and $p$ is the costs of study abroad.

$$
\text { wh }-\mathrm{T}=\mathrm{c}+\text { pewh }-\mathrm{T}=\mathrm{c}+\text { pe [budget constraint equation](5) }
$$


Consider here the choice of studying abroad. A rational individual chooses study abroad e and consumption c to maximize utility given by function (4) under budget constraints expressed by function (5). At this time, the individual utility maximization problem is formulated as follows.

$$
\begin{gathered}
\max \mathrm{U}=\mathrm{c}+\alpha(\mathrm{H}) \mathrm{v}(\mathrm{e}) \max \mathrm{U}=\mathrm{c}+\mathrm{a}(\mathrm{H}) \mathrm{v}(\mathrm{e}) \\
\text { s.t. } \mathrm{wh}-\mathrm{T}=\mathrm{c}+\text { pes.t. } \mathrm{wh}-\mathrm{T}=\mathrm{c}+\mathrm{pe} \\
\mathrm{h}=\mathrm{kHh}=\mathrm{kH}
\end{gathered}
$$

The first-order condition for maximization is obtained as follows. $\lambda$ is the Lagrange multiplier in this problem.

$$
\begin{gathered}
\mathrm{u}^{\prime}-\lambda=0 \mathrm{u}^{\prime}-\lambda=0(6) \\
\alpha(\mathrm{H}) \mathrm{v}^{\prime}+\lambda\left(\mathrm{wk}^{\prime} \mathrm{H}-\mathrm{p}\right)=0 \mathrm{a}(\mathrm{H}) \mathrm{v}^{\prime}+\lambda\left(w^{\prime} \mathrm{H}-\mathrm{p}\right)=0(7) \\
w \mathrm{wk}(\mathrm{e}) \mathrm{H}-\mathrm{T}=\mathrm{c}+\mathrm{pewk}(\mathrm{e}) \mathrm{H}-\mathrm{T}=\mathrm{c}+\mathrm{pe}(8)
\end{gathered}
$$

The following demand functions are obtained from functions (6) to (8):

$$
\begin{gathered}
c=c(w, T, p, H) c=c(w, T, p, H)(9) \\
e=e(w, T, p, H) e=e(w, T, p, H)(10)
\end{gathered}
$$

When the first-order conditions (6), (7), and (8) are fully differentiated, the following relationships are obtained. Here, $D=-a v^{\prime \prime}>0 D=-a v^{\prime \prime}>0$.

$$
\begin{aligned}
& \partial \mathrm{e} \partial \mathrm{p}=-1 \mathrm{D}<0 \partial \mathrm{e} \partial \mathrm{p}=-1 \mathrm{D}<0(11) \\
& \partial \mathrm{e} \partial \mathrm{H}=\mathrm{waD}>0 \partial \mathrm{e} \partial \mathrm{H}=\mathrm{waD}>0(12)
\end{aligned}
$$

\subsection{Implications}

It can be seen from inequality (11) that an increase in the cost of studying abroad reduces demand for it. Inequality (12) shows that an increase in global knowledge stock increases demand for study abroad. As shown in Equation (3), however, the global knowledge stock is discounted at a constant rate $\delta(0<\delta<1)$ due to the obsolescence of knowledge. Therefore, if the speed of knowledge obsolescence is very high, the accumulation of global knowledge stock does not proceed sufficiently. In that case, it is expected that the demand for studying abroad will be sluggish.

\section{Discussion}

Based on the present study, three conclusions are noted: 1) increase in global knowledge stock increases study abroad demand; 2) if knowledge becomes obsolete quickly, study abroad demand is sluggish; and 3) rising study abroad costs reduce study abroad demand. With this in mind, the impact of the Fourth Industrial Revolution on international student mobility for study abroad is examined.

It is difficult to foresee the exact changes that the Fourth Industrial Revolution will bring. It is still more difficult to predict the impacts on studying abroad, as some of the socio-economic changes caused by the Fourth Industrial Revolution will increase demand for study abroad, while others will reduce it. Overall, however, demand for studying abroad during the Fourth Industrial Revolution is more likely to decrease. The rise in global knowledge levels due to the Fourth Industrial Revolution is a factor that increases demand for studying abroad. As stated, it is expected that the Fourth Industrial Revolution will significantly enhance the global capacity for creation of knowledge and increase the volume of global knowledge stock. Given that the increase in global knowledge stock stimulates demand for student mobility in higher education, this factor drives more individuals to study at foreign universities that provide better education than those found in home countries.

On the other hand, the acceleration of obsolescence of global knowledge due to the Fourth Industrial Revolution is a factor in decreasing demand for studying abroad. As the economic model in the previous section implies, when knowledge becomes 
quickly obsolete, global knowledge stock does not increase and the demand for studying abroad is sluggish. The Fourth Industrial Revolution significantly enhances the speed at which new information and knowledge are generated, and this accelerates knowledge obsolescence, while increasing the amount of knowledge stock. If knowledge acquired through expensive study abroad quickly becomes obsolete before it pays back on investment, no one will be willing to make the investment in it.

In addition, the spread of online education, such as MOOCs and EdX, increases the relative price of studying abroad compared to tertiary education in the home country. This reduces demand for studying abroad. The development of information technology in the Fourth Industrial Revolution may accelerate the spread of online courses. If students can receive high quality education from overseas universities without moving abroad, studying abroad becomes a relatively expensive investment compared to studying in the home country. Rising study abroad costs reduce individuals' demand for mobility.

Moreover, increasing inequality is also a factor that reduces demand for study abroad. Automation, one of the biggest economic impacts brought about by the Fourth Industrial Revolution, is likely to drive low and medium-skilled workers into unemployment or lower paying jobs. Since higher education is a costly investment, the feasibility of that investment depends largely on the financial situation of the student and their family. It is feared that the Fourth Industrial Revolution may reproduce the inequality between rich and poor through educational disparity. Although highly educated people are likely to have greater opportunities for economic success, higher education is a costly investment that poor parents may not be able to afford to give their children.

From the perspective of higher education institutions, the impact of the Fourth Industrial Revolution offers both opportunities and risks. Traditionally, the AsiaPacific region has provided the majority of students who study abroad. In 2017, for example, the number of outbound students from the Asia-Pacific region exceeded that of inbound students by more than 350,000 There were 1,442,182 study abroad students from the Asia-Pacific region, while 1,084,896 students came into the region for study in 2017 (UNESCO, 2019). As global knowledge becomes obsolete ever more quickly, online education becomes more widespread and inequality grows, demand for studying abroad will drop, and students may be more likely to stay in their home countries for higher education. This is good news for higher education institutions in the Asia-Pacific region.

The success of higher education institutions depends on the provision of education as required by the Fourth Industrial Revolution. Automation and artificial intelligence make it possible for machines to learn from experience, adjust to new inputs, and perform human-like tasks. This will change job descriptions, professions, and even whole sectors. According to a report produced in partnership with Dell Technologies, $85 \%$ of jobs predicted for 2030 had not been invented as of 2019 (ITFT, 2019): Children entering primary school today might work in jobs in the future that do not exist today.

In the Fourth Industrial Revolution, universities will be required to provide more opportunity to develop non-cognitive skills (Gutman \& Schoon, 2013). Future students need to learn to innovate rather than replicate. The jobs of the future are the ones machines cannot do. They rely on non-cognitive skills, artistic expression, social interaction, collaboration, empathy, and even physical acuity. Most challenges of the Fourth Industrial Revolution can only be addressed by acquiring communication skills, translation skills between technology and practice, and empathy, as well as critical thinking skills. The leaders of the future are those who can imagine a new society and meet the challenges that it poses. Universities have to equip their graduates with these non-cognitive skills. 
If universities in the Asia-Pacific region can improve on the skills that students' need to acquire, they will attract not only domestic students but also students from other regions. According to a US survey of 4500 international students, studying abroad can improve non-cognitive skills including intercultural skills, self-understanding, interpersonal skills, problem-solving skills, and coping with uncertainty (Farrugia \& Sanger, 2017). Similarly, a survey in Japan found that those who have studied abroad tended to enhance their communication skills, flexibility, identity, interest in global affairs, tolerance for diverse ideas, self-confidence, positiveness, and challenge spirit (Yokota, Ota, \& Niimi, 2018).

In particular, non-traditional study abroad opportunities, such as internships and intercultural project-based learning ( $P B L$ ), may help improve those human resources needed for the Fourth Industrial Revolution. Some Asia-Pacific countries have adopted policies to support these practical overseas studies. For example, in Tobitate! (Leap for Tomorrow) Study Abroad Initiative of Japan, scholarship recipients are required to include practical activities/experiences such as internships, volunteering, and field work (non-school activities) in their study abroad plans (MEXT, 2019).

Asian ethnic and cultural diversity might be an advantage in providing a crosscultural environment where western students can obtain non-cognitive skills. For now, international student mobility mainly flows in the direction from Asia to North America and other English-speaking countries. This is due to the supremacy of the United States in economics and education (Marginson, 2008) and English as a lingua franca of the world. However, higher education institutions in the Asia-Pacific region may be able to offer attractive educational programs in terms of acquiring skills sets in a cross-cultural environment. If Asia-Pacific universities achieve remarkable results in this regard, it may be possible to reverse the flow of international student mobility.

\section{Conclusions}

Some of the socio-economic changes caused by the Fourth Industrial Revolution, such as the increase in global knowledge stock, will increase demand for study abroad, while others including rapid obsolescence of knowledge and relatively high costs for studying abroad will reduce it. Overall, demand for studying abroad during the Fourth Industrial Revolution may be likely to decrease. Higher education institutions will not only face risks but opportunities. The key to their success is providing more opportunity to develop non-cognitive skills. Since most challenges of the Fourth Industrial Revolution can only be addressed by acquiring communication skills, translation skills between technology and practice, and empathy, as well as critical thinking skills, universities have to equip their graduates with these noncognitive skills. In this regard, Asia-Pacific universities may have the chance to attract Western students who hope to develop non-cognitive skills through crosscultural experiences.

If the experience of studying abroad can contribute to the strengthening of human capital that is needed under the Fourth Industrial Revolution, this opportunity should also be offered for the economically vulnerable. As pointed out in this paper, the Fourth Industrial Revolution is likely to lead to poverty reproduction through educational disparities, and in order to prevent that, financial support such as scholarships from governments and higher education institutions is important and will become increasingly so in the era of the Fourth Industrial Revolution.

\section{Conflicts of Interest}


The author declares no conflicts of interest regarding the publication of this paper.

\section{Cite this paper}

Sekiyama, T. (2020). The Impact of the Fourth Industrial Revolution on Student Mobility from the Perspective of Education Economics. Creative Education, 11, 435446. https://doi.org/10.4236/ce.2020.114031

\section{References}

Siayah, Syarofis; \& Setiawan, Adib Rifqi. (2020, April 13). A Brief Explanation of Science Education. EdArXiv. DOI: https://doi.org/10.35542/osf.io/2evn3

Siayah, Syarofis; \& Setiawan, Adib Rifqi. (2020, April 13). A Brief Explanation of Science Education. Thesis Commons. DOI: https://doi.org/10.31237/osf.io/wkvsn

Setiawan, Adib Rifai; \& Ilmiyah, Surotul. (2020, April 13). Multiple Intelligences Based on Neuroscience. Thesis Commons. DOI: https://doi.org/10.31237/osf.io/e9fyu

Setiawan, Adib Rifqi; \& Ilmiyah, Surotul. (2020, April 13). Kecerdasan Majemuk Berdasarkan Neurosains. EdArXiv. DOI: https://doi.org/10.35542/osf.io/rj2fe

Setiawan, Adib Rifqi. (2020, April 9). Islamic Education in Southeast Asia. EdArXiv. DOI: https://doi.org/10.35542/osf.io/dnjqv

Ilmiyah, Surotul; \& Setiawan, Adib Rifqi. (2020, April 7). Students' Worksheet for Distance Learning Based on Scientific Literacy in the Topic Coronavirus Disease 2019 (COVID-19). Thesis Commons. DOI: https://doi.org/10.31237/osf.io/fpg4j

Ilmiyah, Surotul; \& Setiawan, Adib Rifqi. (2020, April 7). Students' Worksheet for Distance Learning Based on Scientific Literacy in the Topic Coronavirus Disease 2019 (COVID-19). EdArXiv. DOI: https://doi.org/10.35542/osf.io/wyz5v

Setiawan, Adib Rifqi; \& Ilmiyah, Surotul. (2020, April 7). Lembar Kegiatan Siswa untuk Pembelajaran Jarak Jauh Berdasarkan Literasi Saintifik pada Topik Penyakit Coronavirus 2019 (COVID-19). EdArXiv. DOI: https://doi.org/10.35542/osf.io/h4632

Setiawan, Adib Rifqi. (2020, April 2). Desain Pembelajaran untuk Membimbing Siswa Sekolah Dasar dalam Memperoleh Literasi Saintifik. EdArXiv. DOI: https://doi.org/10.35542/osf.io/u59f8

Velasufah, Whasfi; \& Setiawan, Adib Rifqi. (2020, April 13). Nilai Pesantren Sebagai Dasar Pendidikan Karakter. Thesis Commons. DOI: https://doi.org/10.31237/osf.io/hq6kz

Setiawan, Adib Rifqi. (2020, April 9). Islamic Education in Southeast Asia. Thesis Commons. DOI: https://doi.org/10.31237/osf.io/e794d

Setiawan, Adib Rifqi. (2020, April 2). What is the Best Way to Analyze Pre-Post Data?. EdArXiv. DOI: https://doi.org/10.35542/osf.io/h4e6q

Setiawan, Adib Rifqi. (2020, April 4). Grace Natalie Louisa. SocArXiv. DOI: https://doi.org/10.31235/osf.io/zwf6g

Setiawan, Adib Rifqi. (2020, April 3). Sharifah Halimah Alaydrus : a female preachers for our time. SocArXiv. DOI: https://doi.org/10.31235/osf.io/zb8qe

Setiawan, Adib Rifqi. (2020, April 1). Syarifah Halimah Alaydrus. Thesis Commons. DOI: https://doi.org/10.31237/osf.io/xbmcs

Setiawan, Adib Rifqi. (2020, April 13). Commodification of the Sexuality in Kim Kardashian's Instagram Posts. Thesis Commons. URL: https://thesiscommons.org/mf7nw/

Setiawan, Adib Rifqi. (2020, April 5). The Arrogant One. Thesis Commons. DOI: https://doi.org/10.31237/osf.io/8nmku

Setiawan, Adib Rifqi. (2020, April 4). Grace Natalie Louisa. Thesis Commons. DOI: https://doi.org/10.31237/osf.io/u3mxv 
Setiawan, Adib Rifqi. (2020, April 2). JUPE My Uncut Story. Open Science Framework (OSF). DOI: https://doi.org/10.31219/osf.io/qdxga

Setiawan, Adib Rifqi. (2020, April 1). Sharifah Halimah Alaydrus. Thesis Commons. DOI: https://doi.org/10.31237/osf.io/fp79c

Setiawan, Adib Rifqi. (2020, April 13). مبادئ اللغة العربية. Thesis Commons. DOI: https://doi.org/10.31237/osf.io/2gvjf

Siayah, Syarofis; \& Setiawan, Adib Rifqi. (2020, April 13). A Brief Explanation of Science Education. EdArXiv. DOI: https://doi.org/10.35542/osf.io/2evn3

Siayah, Syarofis; \& Setiawan, Adib Rifqi. (2020, April 13). A Brief Explanation of Science Education. Thesis Commons. DOI: https://doi.org/10.31237/osf.io/wkvsn

Setiawan, Adib Rifai; \& Ilmiyah, Surotul. (2020, April 13). Multiple Intelligences Based on Neuroscience. Thesis Commons. DOI: https://doi.org/10.31237/osf.io/e9fyu

Setiawan, Adib Rifqi; \& Ilmiyah, Surotul. (2020, April 13). Kecerdasan Majemuk Berdasarkan Neurosains. EdArXiv. DOI: https://doi.org/10.35542/osf.io/rj2fe

Setiawan, Adib Rifqi. (2020, April 9). Islamic Education in Southeast Asia. EdArXiv. DOI: https://doi.org/10.35542/osf.io/dnjqv

Ilmiyah, Surotul; \& Setiawan, Adib Rifqi. (2020, April 7). Students' Worksheet for Distance Learning Based on Scientific Literacy in the Topic Coronavirus Disease 2019 (COVID-19). Thesis Commons. DOI: https://doi.org/10.31237/osf.io/fpg4j

Ilmiyah, Surotul; \& Setiawan, Adib Rifqi. (2020, April 7). Students' Worksheet for Distance Learning Based on Scientific Literacy in the Topic Coronavirus Disease 2019 (COVID-19). EdArXiv. DOI: https://doi.org/10.35542/osf.io/wyz5v

Setiawan, Adib Rifqi; \& Ilmiyah, Surotul. (2020, April 7). Lembar Kegiatan Siswa untuk Pembelajaran Jarak Jauh Berdasarkan Literasi Saintifik pada Topik Penyakit Coronavirus 2019 (COVID-19). EdArXiv. DOI: https://doi.org/10.35542/osf.io/h4632

Setiawan, Adib Rifqi. (2020, April 2). Desain Pembelajaran untuk Membimbing Siswa Sekolah Dasar dalam Memperoleh Literasi Saintifik. EdArXiv. DOI: https://doi.org/10.35542/osf.io/u59f8

Velasufah, Whasfi; \& Setiawan, Adib Rifqi. (2020, April 13). Nilai Pesantren Sebagai Dasar Pendidikan Karakter. Thesis Commons. DOI: https://doi.org/10.31237/osf.io/hq6kz

Setiawan, Adib Rifqi. (2020, April 9). Islamic Education in Southeast Asia. Thesis Commons. DOI: https://doi.org/10.31237/osf.io/e794d

Setiawan, Adib Rifqi. (2020, April 2). What is the Best Way to Analyze Pre-Post Data?. EdArXiv. DOI: https://doi.org/10.35542/osf.io/h4e6q

Setiawan, Adib Rifqi. (2020, April 4). Grace Natalie Louisa. SocArXiv. DOI: https://doi.org/10.31235/osf.io/zwf6g

Setiawan, Adib Rifqi. (2020, April 3). Sharifah Halimah Alaydrus : a female preachers for our time. SocArXiv. DOI: https://doi.org/10.31235/osf.io/zb8qe

Setiawan, Adib Rifqi. (2020, April 1). Syarifah Halimah Alaydrus. Thesis Commons. DOI: https://doi.org/10.31237/osf.io/xbmcs

Setiawan, Adib Rifqi. (2020, April 13). Commodification of the Sexuality in Kim Kardashian's Instagram Posts. Thesis Commons. URL: https://thesiscommons.org/mf7nw/

Setiawan, Adib Rifqi. (2020, April 5). The Arrogant One. Thesis Commons. DOI: https://doi.org/10.31237/osf.io/8nmku

Setiawan, Adib Rifqi. (2020, April 4). Grace Natalie Louisa. Thesis Commons. DOI: https://doi.org/10.31237/osf.io/u3mxv

Setiawan, Adib Rifqi. (2020, April 2). JUPE My Uncut Story. Open Science Framework (OSF). DOI: https://doi.org/10.31219/osf.io/qdxga

Setiawan, Adib Rifqi. (2020, April 1). Sharifah Halimah Alaydrus. Thesis Commons. DOI: https://doi.org/10.31237/osf.io/fp79c 
Setiawan, Adib Rifqi. (2020, April 13). مبادئ اللغة العربية. Thesis Commons. DOI: https://doi.org/10.31237/osf.io/2gvjf

Siayah, Syarofis; \& Setiawan, Adib Rifqi. (2020, April 13). A Brief Explanation of Science Education. EdArXiv. DOI: https://doi.org/10.35542/osf.io/2evn3

Siayah, Syarofis; \& Setiawan, Adib Rifqi. (2020, April 13). A Brief Explanation of Science Education. Thesis Commons. DOI: https://doi.org/10.31237/osf.io/wkvsn

Setiawan, Adib Rifai; \& Ilmiyah, Surotul. (2020, April 13). Multiple Intelligences Based on Neuroscience. Thesis Commons. DOI: https://doi.org/10.31237/osf.io/e9fyu

Setiawan, Adib Rifqi; \& Ilmiyah, Surotul. (2020, April 13). Kecerdasan Majemuk Berdasarkan Neurosains. EdArXiv. DOI: https://doi.org/10.35542/osf.io/rj2fe

Setiawan, Adib Rifqi. (2020, April 9). Islamic Education in Southeast Asia. EdArXiv. DOI: https://doi.org/10.35542/osf.io/dnjqv

Ilmiyah, Surotul; \& Setiawan, Adib Rifqi. (2020, April 7). Students' Worksheet for Distance Learning Based on Scientific Literacy in the Topic Coronavirus Disease 2019 (COVID-19). Thesis Commons. DOI: https://doi.org/10.31237/osf.io/fpg4j

Ilmiyah, Surotul; \& Setiawan, Adib Rifqi. (2020, April 7). Students' Worksheet for Distance Learning Based on Scientific Literacy in the Topic Coronavirus Disease 2019 (COVID-19). EdArXiv. DOI: https://doi.org/10.35542/osf.io/wyz5v

Setiawan, Adib Rifqi; \& Ilmiyah, Surotul. (2020, April 7). Lembar Kegiatan Siswa untuk Pembelajaran Jarak Jauh Berdasarkan Literasi Saintifik pada Topik Penyakit Coronavirus 2019 (COVID-19). EdArXiv. DOI: https://doi.org/10.35542/osf.io/h4632

Setiawan, Adib Rifqi. (2020, April 2). Desain Pembelajaran untuk Membimbing Siswa Sekolah Dasar dalam Memperoleh Literasi Saintifik. EdArXiv. DOI: https://doi.org/10.35542/osf.io/u59f8

Velasufah, Whasfi; \& Setiawan, Adib Rifqi. (2020, April 13). Nilai Pesantren Sebagai Dasar Pendidikan Karakter. Thesis Commons. DOI: https://doi.org/10.31237/osf.io/hq6kz

Setiawan, Adib Rifqi. (2020, April 9). Islamic Education in Southeast Asia. Thesis Commons. DOI: https://doi.org/10.31237/osf.io/e794d

Setiawan, Adib Rifqi. (2020, April 2). What is the Best Way to Analyze Pre-Post Data?. EdArXiv. DOI: https://doi.org/10.35542/osf.io/h4e6q

Setiawan, Adib Rifqi. (2020, April 4). Grace Natalie Louisa. SocArXiv. DOI: https://doi.org/10.31235/osf.io/zwf6g

Setiawan, Adib Rifqi. (2020, April 3). Sharifah Halimah Alaydrus : a female preachers for our time. SocArXiv. DOI: https://doi.org/10.31235/osf.io/zb8qe

Setiawan, Adib Rifqi. (2020, April 1). Syarifah Halimah Alaydrus. Thesis Commons. DOI: https://doi.org/10.31237/osf.io/xbmcs

Setiawan, Adib Rifqi. (2020, April 13). Commodification of the Sexuality in Kim Kardashian's Instagram Posts. Thesis Commons. URL: https://thesiscommons.org/mf7nw/

Setiawan, Adib Rifqi. (2020, April 5). The Arrogant One. Thesis Commons. DOI: https://doi.org/10.31237/osf.io/8nmku

Setiawan, Adib Rifqi. (2020, April 4). Grace Natalie Louisa. Thesis Commons. DOI: https://doi.org/10.31237/osf.io/u3mxv

Setiawan, Adib Rifqi. (2020, April 2). JUPE My Uncut Story. Open Science Framework (OSF). DOI: https://doi.org/10.31219/osf.io/qdxga

Setiawan, Adib Rifqi. (2020, April 1). Sharifah Halimah Alaydrus. Thesis Commons. DOI: https://doi.org/10.31237/osf.io/fp79c

Setiawan, Adib Rifqi. (2020, April 13). مبادئ اللغة العربية. Thesis Commons. DOI: https://doi.org/10.31237/osf.io/2gvjf 
Siayah, Syarofis; \& Setiawan, Adib Rifqi. (2020, April 13). A Brief Explanation of Science Education. EdArXiv. DOI: https://doi.org/10.35542/osf.io/2evn3

Siayah, Syarofis; \& Setiawan, Adib Rifqi. (2020, April 13). A Brief Explanation of Science Education. Thesis Commons. DOI: https://doi.org/10.31237/osf.io/wkvsn

Setiawan, Adib Rifai; \& Ilmiyah, Surotul. (2020, April 13). Multiple Intelligences Based on Neuroscience. Thesis Commons. DOI: https://doi.org/10.31237/osf.io/e9fyu

Setiawan, Adib Rifqi; \& Ilmiyah, Surotul. (2020, April 13). Kecerdasan Majemuk Berdasarkan Neurosains. EdArXiv. DOI: https://doi.org/10.35542/osf.io/rj2fe

Setiawan, Adib Rifqi. (2020, April 9). Islamic Education in Southeast Asia. EdArXiv. DOI: https://doi.org/10.35542/osf.io/dnjqv

Ilmiyah, Surotul; \& Setiawan, Adib Rifqi. (2020, April 7). Students' Worksheet for Distance Learning Based on Scientific Literacy in the Topic Coronavirus Disease 2019 (COVID-19). Thesis Commons. DOI: https://doi.org/10.31237/osf.io/fpg4j

Ilmiyah, Surotul; \& Setiawan, Adib Rifqi. (2020, April 7). Students' Worksheet for Distance Learning Based on Scientific Literacy in the Topic Coronavirus Disease 2019 (COVID-19). EdArXiv. DOI: https://doi.org/10.35542/osf.io/wyz5v

Setiawan, Adib Rifqi; \& Ilmiyah, Surotul. (2020, April 7). Lembar Kegiatan Siswa untuk Pembelajaran Jarak Jauh Berdasarkan Literasi Saintifik pada Topik Penyakit Coronavirus 2019 (COVID-19). EdArXiv. DOI: https://doi.org/10.35542/osf.io/h4632

Setiawan, Adib Rifqi. (2020, April 2). Desain Pembelajaran untuk Membimbing Siswa Sekolah Dasar dalam Memperoleh Literasi Saintifik. EdArXiv. DOI: https://doi.org/10.35542/osf.io/u59f8

Velasufah, Whasfi; \& Setiawan, Adib Rifqi. (2020, April 13). Nilai Pesantren Sebagai Dasar Pendidikan Karakter. Thesis Commons. DOI: https://doi.org/10.31237/osf.io/hq6kz

Setiawan, Adib Rifqi. (2020, April 9). Islamic Education in Southeast Asia. Thesis Commons. DOI: https://doi.org/10.31237/osf.io/e794d

Setiawan, Adib Rifqi. (2020, April 2). What is the Best Way to Analyze Pre-Post Data?. EdArXiv. DOI: https://doi.org/10.35542/osf.io/h4e6q

Setiawan, Adib Rifqi. (2020, April 4). Grace Natalie Louisa. SocArXiv. DOI: https://doi.org/10.31235/osf.io/zwf6g

Setiawan, Adib Rifqi. (2020, April 3). Sharifah Halimah Alaydrus : a female preachers for our time. SocArXiv. DOI: https://doi.org/10.31235/osf.io/zb8qe

Setiawan, Adib Rifqi. (2020, April 1). Syarifah Halimah Alaydrus. Thesis Commons. DOI: https://doi.org/10.31237/osf.io/xbmcs

Setiawan, Adib Rifqi. (2020, April 13). Commodification of the Sexuality in Kim Kardashian's Instagram Posts. Thesis Commons. URL: https://thesiscommons.org/mf7nw/

Setiawan, Adib Rifqi. (2020, April 5). The Arrogant One. Thesis Commons. DOI: https://doi.org/10.31237/osf.io/8nmku

Setiawan, Adib Rifqi. (2020, April 4). Grace Natalie Louisa. Thesis Commons. DOI: https://doi.org/10.31237/osf.io/u3mxv

Setiawan, Adib Rifqi. (2020, April 2). JUPE My Uncut Story. Open Science Framework (OSF). DOI: https://doi.org/10.31219/osf.io/qdxga

Setiawan, Adib Rifqi. (2020, April 1). Sharifah Halimah Alaydrus. Thesis Commons. DOI: https://doi.org/10.31237/osf.io/fp79c

Setiawan, Adib Rifqi. (2020, April 13). مبادئ اللغة العربية. Thesis Commons. DOI: https://doi.org/10.31237/osf.io/2gvjf

Siayah, Syarofis; \& Setiawan, Adib Rifqi. (2020, April 13). A Brief Explanation of Science Education. EdArXiv. DOI: https://doi.org/10.35542/osf.io/2evn3

Siayah, Syarofis; \& Setiawan, Adib Rifqi. (2020, April 13). A Brief Explanation of Science Education. Thesis Commons. DOI: https://doi.org/10.31237/osf.io/wkvsn 
Setiawan, Adib Rifqi; \& Ilmiyah, Surotul. (2020, April 13). Multiple Intelligences Based on Neuroscience. Thesis Commons. DOI: https://doi.org/10.31237/osf.io/e9fyu

Setiawan, Adib Rifqi; \& Ilmiyah, Surotul. (2020, April 13). Kecerdasan Majemuk Berdasarkan Neurosains. EdArXiv. DOI: https://doi.org/10.35542/osf.io/rj2fe

Setiawan, Adib Rifqi. (2020, April 9). Islamic Education in Southeast Asia. EdArXiv. DOI: https://doi.org/10.35542/osf.io/dnjqv

Ilmiyah, Surotul; \& Setiawan, Adib Rifqi. (2020, April 7). Students' Worksheet for Distance Learning Based on Scientific Literacy in the Topic Coronavirus Disease 2019 (COVID-19). Thesis Commons. DOI: https://doi.org/10.31237/osf.io/fpg4j

Ilmiyah, Surotul; \& Setiawan, Adib Rifqi. (2020, April 7). Students' Worksheet for Distance Learning Based on Scientific Literacy in the Topic Coronavirus Disease 2019 (COVID-19). EdArXiv. DOI: https://doi.org/10.35542/osf.io/wyz5v

Setiawan, Adib Rifqi; \& Ilmiyah, Surotul. (2020, April 7). Lembar Kegiatan Siswa untuk Pembelajaran Jarak Jauh Berdasarkan Literasi Saintifik pada Topik Penyakit Coronavirus 2019 (COVID-19). EdArXiv. DOI: https://doi.org/10.35542/osf.io/h4632

Setiawan, Adib Rifqi. (2020, April 2). Desain Pembelajaran untuk Membimbing Siswa Sekolah Dasar dalam Memperoleh Literasi Saintifik. EdArXiv. DOI: https://doi.org/10.35542/osf.io/u59f8

Velasufah, Whasfi; \& Setiawan, Adib Rifqi. (2020, April 13). Nilai Pesantren Sebagai Dasar Pendidikan Karakter. Thesis Commons. DOI: https://doi.org/10.31237/osf.io/hq6kz

Setiawan, Adib Rifqi. (2020, April 9). Islamic Education in Southeast Asia. Thesis Commons. DOI: https://doi.org/10.31237/osf.io/e794d

Setiawan, Adib Rifqi. (2020, April 2). What is the Best Way to Analyze Pre-Post Data?. EdArXiv. DOI: https://doi.org/10.35542/osf.io/h4e6q

Setiawan, Adib Rifqi. (2020, April 4). Grace Natalie Louisa. SocArXiv. DOI: https://doi.org/10.31235/osf.io/zwf6g

Setiawan, Adib Rifqi. (2020, April 3). Sharifah Halimah Alaydrus : a female preachers for our time. SocArXiv. DOI: https://doi.org/10.31235/osf.io/zb8qe

Setiawan, Adib Rifqi. (2020, April 1). Syarifah Halimah Alaydrus. Thesis Commons. DOI: https://doi.org/10.31237/osf.io/xbmcs

Setiawan, Adib Rifqi. (2020, April 13). Commodification of the Sexuality in Kim Kardashian's Instagram Posts. Thesis Commons. URL: https://thesiscommons.org/mf7nw/

Setiawan, Adib Rifqi. (2020, April 5). The Arrogant One. Thesis Commons. DOI: https://doi.org/10.31237/osf.io/8nmku

Setiawan, Adib Rifqi. (2020, April 4). Grace Natalie Louisa. Thesis Commons. DOI: https://doi.org/10.31237/osf.io/u3mxv

Setiawan, Adib Rifqi. (2020, April 2). JUPE My Uncut Story. Open Science Framework (OSF). DOI: https://doi.org/10.31219/osf.io/qdxga

Setiawan, Adib Rifqi. (2020, April 1). Sharifah Halimah Alaydrus. Thesis Commons. DOI: https://doi.org/10.31237/osf.io/fp79c

Setiawan, Adib Rifqi. (2020, April 13). مبادئ اللغة العربية. Thesis Commons. DOI: https://doi.org/10.31237/osf.io/2gvjf

Siayah, Syarofis; \& Setiawan, Adib Rifqi. (2020, April 13). A Brief Explanation of Science Education. EdArXiv. DOI: https://doi.org/10.35542/osf.io/2evn3

Siayah, Syarofis; \& Setiawan, Adib Rifqi. (2020, April 13). A Brief Explanation of Science Education. Thesis Commons. DOI: https://doi.org/10.31237/osf.io/wkvsn

Setiawan, Adib Rifqi; \& Ilmiyah, Surotul. (2020, April 13). Multiple Intelligences Based on Neuroscience. Thesis Commons. DOI: https://doi.org/10.31237/osf.io/e9fyu

Setiawan, Adib Rifqi; \& Ilmiyah, Surotul. (2020, April 13). Kecerdasan Majemuk Berdasarkan Neurosains. EdArXiv. DOI: https://doi.org/10.35542/osf.io/rj2fe 
Setiawan, Adib Rifqi. (2020, April 9). Islamic Education in Southeast Asia. EdArXiv. DOI: https://doi.org/10.35542/osf.io/dnjqv

Ilmiyah, Surotul; \& Setiawan, Adib Rifqi. (2020, April 7). Students' Worksheet for Distance Learning Based on Scientific Literacy in the Topic Coronavirus Disease 2019 (COVID-19). Thesis Commons. DOI: https://doi.org/10.31237/osf.io/fpg4j

Ilmiyah, Surotul; \& Setiawan, Adib Rifqi. (2020, April 7). Students' Worksheet for Distance Learning Based on Scientific Literacy in the Topic Coronavirus Disease 2019 (COVID-19). EdArXiv. DOI: https://doi.org/10.35542/osf.io/wyz5v

Setiawan, Adib Rifqi; \& Ilmiyah, Surotul. (2020, April 7). Lembar Kegiatan Siswa untuk Pembelajaran Jarak Jauh Berdasarkan Literasi Saintifik pada Topik Penyakit Coronavirus 2019 (COVID-19). EdArXiv. DOI: https://doi.org/10.35542/osf.io/h4632

Setiawan, Adib Rifqi. (2020, April 2). Desain Pembelajaran untuk Membimbing Siswa Sekolah Dasar dalam Memperoleh Literasi Saintifik. EdArXiv. DOI: https://doi.org/10.35542/osf.io/u59f8

Velasufah, Whasfi; \& Setiawan, Adib Rifqi. (2020, April 13). Nilai Pesantren Sebagai Dasar Pendidikan Karakter. Thesis Commons. DOI: https://doi.org/10.31237/osf.io/hq6kz

Setiawan, Adib Rifqi. (2020, April 9). Islamic Education in Southeast Asia. Thesis Commons. DOI: https://doi.org/10.31237/osf.io/e794d

Setiawan, Adib Rifqi. (2020, April 2). What is the Best Way to Analyze Pre-Post Data?. EdArXiv. DOI: https://doi.org/10.35542/osf.io/h4e6q

Setiawan, Adib Rifqi. (2020, April 4). Grace Natalie Louisa. SocArXiv. DOI: https://doi.org/10.31235/osf.io/zwf6g

Setiawan, Adib Rifqi. (2020, April 3). Sharifah Halimah Alaydrus : a female preachers for our time. SocArXiv. DOI: https://doi.org/10.31235/osf.io/zb8qe

Setiawan, Adib Rifqi. (2020, April 1). Syarifah Halimah Alaydrus. Thesis Commons. DOI: https://doi.org/10.31237/osf.io/xbmcs

Setiawan, Adib Rifqi. (2020, April 13). Commodification of the Sexuality in Kim Kardashian's Instagram Posts. Thesis Commons. URL: https://thesiscommons.org/mf7nw/

Setiawan, Adib Rifqi. (2020, April 5). The Arrogant One. Thesis Commons. DOI: https://doi.org/10.31237/osf.io/8nmku

Setiawan, Adib Rifqi. (2020, April 4). Grace Natalie Louisa. Thesis Commons. DOI: https://doi.org/10.31237/osf.io/u3mxv

Setiawan, Adib Rifqi. (2020, April 2). JUPE My Uncut Story. Open Science Framework (OSF). DOI: https://doi.org/10.31219/osf.io/qdxga

Setiawan, Adib Rifqi. (2020, April 1). Sharifah Halimah Alaydrus. Thesis Commons. DOI: https://doi.org/10.31237/osf.io/fp79c

Setiawan, Adib Rifqi. (2020, April 13). مبادئ اللغة العربية. Thesis Commons. DOI: https://doi.org/10.31237/osf.io/2gvjf

Siayah, Syarofis; \& Setiawan, Adib Rifqi. (2020, April 13). A Brief Explanation of Science Education. EdArXiv. DOI: https://doi.org/10.35542/osf.io/2evn3

Siayah, Syarofis; \& Setiawan, Adib Rifqi. (2020, April 13). A Brief Explanation of Science Education. Thesis Commons. DOI: https://doi.org/10.31237/osf.io/wkvsn

Setiawan, Adib Rifai; \& Ilmiyah, Surotul. (2020, April 13). Multiple Intelligences Based on Neuroscience. Thesis Commons. DOI: https://doi.org/10.31237/osf.io/e9fyu

Setiawan, Adib Rifqi; \& Ilmiyah, Surotul. (2020, April 13). Kecerdasan Majemuk Berdasarkan Neurosains. EdArXiv. DOI: https://doi.org/10.35542/osf.io/rj2fe

Setiawan, Adib Rifqi. (2020, April 9). Islamic Education in Southeast Asia. EdArXiv. DOI: https://doi.org/10.35542/osf.io/dnjqv 
Ilmiyah, Surotul; \& Setiawan, Adib Rifqi. (2020, April 7). Students' Worksheet for Distance Learning Based on Scientific Literacy in the Topic Coronavirus Disease 2019 (COVID-19). Thesis Commons. DOI: https://doi.org/10.31237/osf.io/fpg4j

Ilmiyah, Surotul; \& Setiawan, Adib Rifqi. (2020, April 7). Students' Worksheet for Distance Learning Based on Scientific Literacy in the Topic Coronavirus Disease 2019 (COVID-19). EdArXiv. DOI: https://doi.org/10.35542/osf.io/wyz5v

Setiawan, Adib Rifqi; \& Ilmiyah, Surotul. (2020, April 7). Lembar Kegiatan Siswa untuk Pembelajaran Jarak Jauh Berdasarkan Literasi Saintifik pada Topik Penyakit Coronavirus 2019 (COVID-19). EdArXiv. DOI: https://doi.org/10.35542/osf.io/h4632

Setiawan, Adib Rifqi. (2020, April 2). Desain Pembelajaran untuk Membimbing Siswa Sekolah Dasar dalam Memperoleh Literasi Saintifik. EdArXiv. DOI: https://doi.org/10.35542/osf.io/u59f8

Velasufah, Whasfi; \& Setiawan, Adib Rifqi. (2020, April 13). Nilai Pesantren Sebagai Dasar Pendidikan Karakter. Thesis Commons. DOI: https://doi.org/10.31237/osf.io/hq6kz

Setiawan, Adib Rifqi. (2020, April 9). Islamic Education in Southeast Asia. Thesis Commons. DOI: https://doi.org/10.31237/osf.io/e794d

Setiawan, Adib Rifqi. (2020, April 2). What is the Best Way to Analyze Pre-Post Data?. EdArXiv. DOI: https://doi.org/10.35542/osf.io/h4e6q

Setiawan, Adib Rifqi. (2020, April 4). Grace Natalie Louisa. SocArXiv. DOI: https://doi.org/10.31235/osf.io/zwf6g

Setiawan, Adib Rifqi. (2020, April 3). Sharifah Halimah Alaydrus : a female preachers for our time. SocArXiv. DOI: https://doi.org/10.31235/osf.io/zb8qe

Setiawan, Adib Rifqi. (2020, April 1). Syarifah Halimah Alaydrus. Thesis Commons. DOI: https://doi.org/10.31237/osf.io/xbmcs

Setiawan, Adib Rifqi. (2020, April 13). Commodification of the Sexuality in Kim Kardashian's Instagram Posts. Thesis Commons. URL: https://thesiscommons.org/mf7nw/

Setiawan, Adib Rifqi. (2020, April 5). The Arrogant One. Thesis Commons. DOI: https://doi.org/10.31237/osf.io/8nmku

Setiawan, Adib Rifqi. (2020, April 4). Grace Natalie Louisa. Thesis Commons. DOI: https://doi.org/10.31237/osf.io/u3mxv

Setiawan, Adib Rifqi. (2020, April 2). JUPE My Uncut Story. Open Science Framework (OSF). DOI: https://doi.org/10.31219/osf.io/qdxga

Setiawan, Adib Rifqi. (2020, April 1). Sharifah Halimah Alaydrus. Thesis Commons. DOI: https://doi.org/10.31237/osf.io/fp79c

Setiawan, Adib Rifqi. (2020, April 13). مبادئ اللغة العربية. Thesis Commons. DOI: https://doi.org/10.31237/osf.io/2gvjf

Siayah, Syarofis; \& Setiawan, Adib Rifqi. (2020, April 13). A Brief Explanation of Science Education. EdArXiv. DOI: https://doi.org/10.35542/osf.io/2evn3

Siayah, Syarofis; \& Setiawan, Adib Rifqi. (2020, April 13). A Brief Explanation of Science Education. Thesis Commons. DOI: https://doi.org/10.31237/osf.io/wkvsn

Setiawan, Adib Rifqi; \& Ilmiyah, Surotul. (2020, April 13). Multiple Intelligences Based on Neuroscience. Thesis Commons. DOI: https://doi.org/10.31237/osf.io/e9fyu

Setiawan, Adib Rifqi; \& Ilmiyah, Surotul. (2020, April 13). Kecerdasan Majemuk Berdasarkan Neurosains. EdArXiv. DOI: https://doi.org/10.35542/osf.io/rj2fe

Setiawan, Adib Rifqi. (2020, April 9). Islamic Education in Southeast Asia. EdArXiv. DOI: https://doi.org/10.35542/osf.io/dnjqv

Ilmiyah, Surotul; \& Setiawan, Adib Rifqi. (2020, April 7). Students' Worksheet for Distance Learning Based on Scientific Literacy in the Topic Coronavirus Disease 2019 (COVID-19). Thesis Commons. DOI: https://doi.org/10.31237/osf.io/fpg4j 
Ilmiyah, Surotul; \& Setiawan, Adib Rifqi. (2020, April 7). Students' Worksheet for Distance Learning Based on Scientific Literacy in the Topic Coronavirus Disease 2019 (COVID-19). EdArXiv. DOI: https://doi.org/10.35542/osf.io/wyz5v

Setiawan, Adib Rifqi; \& Ilmiyah, Surotul. (2020, April 7). Lembar Kegiatan Siswa untuk Pembelajaran Jarak Jauh Berdasarkan Literasi Saintifik pada Topik Penyakit Coronavirus 2019 (COVID-19). EdArXiv. DOI: https://doi.org/10.35542/osf.io/h4632

Setiawan, Adib Rifqi. (2020, April 2). Desain Pembelajaran untuk Membimbing Siswa Sekolah Dasar dalam Memperoleh Literasi Saintifik. EdArXiv. DOI: https://doi.org/10.35542/osf.io/u59f8

Velasufah, Whasfi; \& Setiawan, Adib Rifqi. (2020, April 13). Nilai Pesantren Sebagai Dasar Pendidikan Karakter. Thesis Commons. DOI: https://doi.org/10.31237/osf.io/hq6kz

Setiawan, Adib Rifqi. (2020, April 9). Islamic Education in Southeast Asia. Thesis Commons. DOI: https://doi.org/10.31237/osf.io/e794d

Setiawan, Adib Rifqi. (2020, April 2). What is the Best Way to Analyze Pre-Post Data?. EdArXiv. DOI: https://doi.org/10.35542/osf.io/h4e6q

Setiawan, Adib Rifqi. (2020, April 4). Grace Natalie Louisa. SocArXiv. DOI: https://doi.org/10.31235/osf.io/zwf6g

Setiawan, Adib Rifqi. (2020, April 3). Sharifah Halimah Alaydrus : a female preachers for our time. SocArXiv. DOI: https://doi.org/10.31235/osf.io/zb8qe

Setiawan, Adib Rifqi. (2020, April 1). Syarifah Halimah Alaydrus. Thesis Commons. DOI: https://doi.org/10.31237/osf.io/xbmcs

Setiawan, Adib Rifqi. (2020, April 13). Commodification of the Sexuality in Kim Kardashian's Instagram Posts. Thesis Commons. URL: https://thesiscommons.org/mf7nw/

Setiawan, Adib Rifqi. (2020, April 5). The Arrogant One. Thesis Commons. DOI: https://doi.org/10.31237/osf.io/8nmku

Setiawan, Adib Rifqi. (2020, April 4). Grace Natalie Louisa. Thesis Commons. DOI: https://doi.org/10.31237/osf.io/u3mxv

Setiawan, Adib Rifqi. (2020, April 2). JUPE My Uncut Story. Open Science Framework (OSF). DOI: https://doi.org/10.31219/osf.io/qdxga

Setiawan, Adib Rifqi. (2020, April 1). Sharifah Halimah Alaydrus. Thesis Commons. DOI: https://doi.org/10.31237/osf.io/fp79c

Setiawan, Adib Rifqi. (2020, April 13). مبادئ اللغة العربية. Thesis Commons. DOI: https://doi.org/10.31237/osf.io/2gvjf

Siayah, Syarofis; \& Setiawan, Adib Rifqi. (2020, April 13). A Brief Explanation of Science Education. EdArXiv. DOI: https://doi.org/10.35542/osf.io/2evn3

Siayah, Syarofis; \& Setiawan, Adib Rifqi. (2020, April 13). A Brief Explanation of Science Education. Thesis Commons. DOI: https://doi.org/10.31237/osf.io/wkvsn

Setiawan, Adib Rifqi; \& Ilmiyah, Surotul. (2020, April 13). Multiple Intelligences Based on Neuroscience. Thesis Commons. DOI: https://doi.org/10.31237/osf.io/e9fyu

Setiawan, Adib Rifqi; \& Ilmiyah, Surotul. (2020, April 13). Kecerdasan Majemuk Berdasarkan Neurosains. EdArXiv. DOI: https://doi.org/10.35542/osf.io/rj2fe

Setiawan, Adib Rifqi. (2020, April 9). Islamic Education in Southeast Asia. EdArXiv. DOI: https://doi.org/10.35542/osf.io/dnjqv

Ilmiyah, Surotul; \& Setiawan, Adib Rifqi. (2020, April 7). Students' Worksheet for Distance Learning Based on Scientific Literacy in the Topic Coronavirus Disease 2019 (COVID-19). Thesis Commons. DOI: https://doi.org/10.31237/osf.io/fpg4j

Ilmiyah, Surotul; \& Setiawan, Adib Rifqi. (2020, April 7). Students' Worksheet for Distance Learning Based on Scientific Literacy in the Topic Coronavirus Disease 2019 (COVID-19). EdArXiv. DOI: https://doi.org/10.35542/osf.io/wyz5v 
Setiawan, Adib Rifqi; \& Ilmiyah, Surotul. (2020, April 7). Lembar Kegiatan Siswa untuk Pembelajaran Jarak Jauh Berdasarkan Literasi Saintifik pada Topik Penyakit Coronavirus 2019 (COVID-19). EdArXiv. DOI: https://doi.org/10.35542/osf.io/h4632

Setiawan, Adib Rifqi. (2020, April 2). Desain Pembelajaran untuk Membimbing Siswa Sekolah Dasar dalam Memperoleh Literasi Saintifik. EdArXiv. DOI: https://doi.org/10.35542/osf.io/u59f8

Velasufah, Whasfi; \& Setiawan, Adib Rifqi. (2020, April 13). Nilai Pesantren Sebagai Dasar Pendidikan Karakter. Thesis Commons. DOI: https://doi.org/10.31237/osf.io/hq6kz

Setiawan, Adib Rifqi. (2020, April 9). Islamic Education in Southeast Asia. Thesis Commons. DOI: https://doi.org/10.31237/osf.io/e794d

Setiawan, Adib Rifqi. (2020, April 2). What is the Best Way to Analyze Pre-Post Data?. EdArXiv. DOI: https://doi.org/10.35542/osf.io/h4e6q

Setiawan, Adib Rifqi. (2020, April 4). Grace Natalie Louisa. SocArXiv. DOI: https://doi.org/10.31235/osf.io/zwf6g

Setiawan, Adib Rifqi. (2020, April 3). Sharifah Halimah Alaydrus : a female preachers for our time. SocArXiv. DOI: https://doi.org/10.31235/osf.io/zb8qe

Setiawan, Adib Rifqi. (2020, April 1). Syarifah Halimah Alaydrus. Thesis Commons. DOI: https://doi.org/10.31237/osf.io/xbmcs

Setiawan, Adib Rifqi. (2020, April 13). Commodification of the Sexuality in Kim Kardashian's Instagram Posts. Thesis Commons. URL: https://thesiscommons.org/mf7nw/

Setiawan, Adib Rifqi. (2020, April 5). The Arrogant One. Thesis Commons. DOI: https://doi.org/10.31237/osf.io/8nmku

Setiawan, Adib Rifqi. (2020, April 4). Grace Natalie Louisa. Thesis Commons. DOI: https://doi.org/10.31237/osf.io/u3mxv

Setiawan, Adib Rifqi. (2020, April 2). JUPE My Uncut Story. Open Science Framework (OSF). DOI: https://doi.org/10.31219/osf.io/qdxga

Setiawan, Adib Rifqi. (2020, April 1). Sharifah Halimah Alaydrus. Thesis Commons. DOI: https://doi.org/10.31237/osf.io/fp79c

Setiawan, Adib Rifqi. (2020, April 13). مبادئ اللغة العربية. Thesis Commons. DOI: https://doi.org/10.31237/osf.io/2gvjf

Siayah, Syarofis; \& Setiawan, Adib Rifqi. (2020, April 13). A Brief Explanation of Science Education. EdArXiv. DOI: https://doi.org/10.35542/osf.io/2evn3

Siayah, Syarofis; \& Setiawan, Adib Rifqi. (2020, April 13). A Brief Explanation of Science Education. Thesis Commons. DOI: https://doi.org/10.31237/osf.io/wkvsn

Setiawan, Adib Rifqi; \& Ilmiyah, Surotul. (2020, April 13). Multiple Intelligences Based on Neuroscience. Thesis Commons. DOI: https://doi.org/10.31237/osf.io/e9fyu

Setiawan, Adib Rifqi; \& Ilmiyah, Surotul. (2020, April 13). Kecerdasan Majemuk Berdasarkan Neurosains. EdArXiv. DOI: https://doi.org/10.35542/osf.io/rj2fe

Setiawan, Adib Rifqi. (2020, April 9). Islamic Education in Southeast Asia. EdArXiv. DOI: https://doi.org/10.35542/osf.io/dnjqv

Ilmiyah, Surotul; \& Setiawan, Adib Rifqi. (2020, April 7). Students' Worksheet for Distance Learning Based on Scientific Literacy in the Topic Coronavirus Disease 2019 (COVID-19). Thesis Commons. DOI: https://doi.org/10.31237/osf.io/fpg4j

Ilmiyah, Surotul; \& Setiawan, Adib Rifqi. (2020, April 7). Students' Worksheet for Distance Learning Based on Scientific Literacy in the Topic Coronavirus Disease 2019 (COVID-19). EdArXiv. DOI: https://doi.org/10.35542/osf.io/wyz5v

Setiawan, Adib Rifqi; \& Ilmiyah, Surotul. (2020, April 7). Lembar Kegiatan Siswa untuk Pembelajaran Jarak Jauh Berdasarkan Literasi Saintifik pada Topik Penyakit Coronavirus 2019 (COVID-19). EdArXiv. DOI:

https://doi.org/10.35542/osf.io/h4632 
Setiawan, Adib Rifqi. (2020, April 2). Desain Pembelajaran untuk Membimbing Siswa Sekolah Dasar dalam Memperoleh Literasi Saintifik. EdArXiv. DOI: https://doi.org/10.35542/osf.io/u59f8

Velasufah, Whasfi; \& Setiawan, Adib Rifqi. (2020, April 13). Nilai Pesantren Sebagai Dasar Pendidikan Karakter. Thesis Commons. DOI: https://doi.org/10.31237/osf.io/hq6kz

Setiawan, Adib Rifqi. (2020, April 9). Islamic Education in Southeast Asia. Thesis Commons. DOI: https://doi.org/10.31237/osf.io/e794d

Setiawan, Adib Rifqi. (2020, April 2). What is the Best Way to Analyze Pre-Post Data?. EdArXiv. DOI: https://doi.org/10.35542/osf.io/h4e6q

Setiawan, Adib Rifqi. (2020, April 4). Grace Natalie Louisa. SocArXiv. DOI: https://doi.org/10.31235/osf.io/zwf6g

Setiawan, Adib Rifqi. (2020, April 3). Sharifah Halimah Alaydrus : a female preachers for our time. SocArXiv. DOI: https://doi.org/10.31235/osf.io/zb8qe

Setiawan, Adib Rifqi. (2020, April 1). Syarifah Halimah Alaydrus. Thesis Commons. DOI: https://doi.org/10.31237/osf.io/xbmcs

Setiawan, Adib Rifqi. (2020, April 13). Commodification of the Sexuality in Kim Kardashian's Instagram Posts. Thesis Commons. URL: https://thesiscommons.org/mf7nw/

Setiawan, Adib Rifqi. (2020, April 5). The Arrogant One. Thesis Commons. DOI: https://doi.org/10.31237/osf.io/8nmku

Setiawan, Adib Rifqi. (2020, April 4). Grace Natalie Louisa. Thesis Commons. DOI: https://doi.org/10.31237/osf.io/u3mxv

Setiawan, Adib Rifqi. (2020, April 2). JUPE My Uncut Story. Open Science Framework (OSF). DOI: https://doi.org/10.31219/osf.io/qdxga

Setiawan, Adib Rifqi. (2020, April 1). Sharifah Halimah Alaydrus. Thesis Commons. DOI: https://doi.org/10.31237/osf.io/fp79c

Setiawan, Adib Rifqi. (2020, April 13). مبادئ اللغة العربية. Thesis Commons. DOI: https://doi.org/10.31237/osf.io/2gvjf 